\title{
The Mood and Modality in the Bible: A Systemic Functional Perspective*
}

\author{
Xi Wang \\ College of International Studies, Southwest University, Chongqing, China
}

\begin{abstract}
The Bible is an influential classic whose charm is closely related to its language, especially words spoken by the God. With interpersonal function as its theoretical framework, and the whole Bible (King James Version) as its research text, this paper makes a detailed analysis of the interpersonal meaning in the conversations among God, God's chosen people and other people by statistics and illustration, and finds that mood and modality in biblical language has directly or indirectly helped to make closer relationship between God and his people. Mood and modality in the Bible helps construct positive interpersonal relationships, which is one of the essential sources of the Bible's charm and everlasting effect.
\end{abstract}

Index Terms -Bible, interpersonal meaning, God-human relationship, mood, modality

\section{INTRODUCTION}

The Holy Scripture, or the Bible, is one of the most important religious books in the world. Its influence on the world especially in western countries cannot be matched by any other books. Almost in every corner of the world, the Bible attracts huge numbers of believers. With such an influential book, its charm is closely related to its language, especially words spoken by the God.

Interpersonal function comes from the metafunctions proposed by Halliday. In his systemic functional grammar, interpersonal function refers to the function in which we use language to interact with other people, to establish and maintain relationships with them, to influence their behavior, to express our own viewpoint on things in the world, and to elicit or change other people's opinions. Interpersonal meaning can be realized in various ways, among them, mood and modality are two most important ones.

By taking interpersonal function as the theoretical framework, this article tries to make a detailed analysis of biblical language especially the language of God, and find out the source of the Bible's attraction. In the whole process, the article develops its study from the aspects of mood and modality. The originality of the present research is embodied in two points: first, it examines religious language from the perspective of metafunction; second, it probes into interpersonal meaning from the level of the whole text (Holy Bible, Authorized (King James) Version).

\section{The Status of Language in the Bible}

In the Bible, the world in the Biblical time is created and constructed through language. The very beginning of the Bible saw God's splendid creation of the world. Within just seven days, God finished the creation of the heaven and the earth, filled the world with all necessary elements, and all of the things are simply created through God's words of "Let there be", thus the world has light, air, living creatures. At last, God said "Let us make man in our image, after our likeness", and then it was so (Genesis 1:30). The creation of the world is the miracle of God's way of doing things. God realized the process of growth out of nothing merely by words.

From the above, we can see that language has extremely high status in the Bible. In Hebrew tradition, the word which represents language and the word which means objects is the same word "davar". Therefore, in Hebrew, language has equal or even higher status compared with all the other materials existed in the world.

\section{ANALYSIS OF INTERPERSONAL MEANing OF GOD-HUMAN RELATIONSHIP IN OLD TESTAMENT}

\section{God-human Relationship}

Human in the Bible, who are living in the real world created by God, have dual identities: they are both the ruler of the real world and the subject of God. But this freewill and control over other living things are also assigned by the divine God, as we can see in "And God said, Let us make man in our image, after our likeness: and let them have dominion over the fish of the sea, and over the fowl of the air, and over the cattle, and over all the earth, and over every creeping thing that creeps on the earth."(Genesis 1:26). Therefore, human hope to get rid of the state of being constrained. Through constant betrayal, rebellion and resistance, they are trying to gain more freedom and knowledge from God and improve their subjective status. However, the omnipotent, omnipresent and omniscience God obviously

\footnotetext{
* This work is supported by Language Complexity and Its Application in Language Teaching (SWU1309342), Special Fund of Southwest University Central Basic Scientific Research in Colleges and Universities.
} 
worried about the rebellion, constantly punishing human and preventing them from any attempts.

Ever since Adam and Eve ate the forbidden fruit, they broke the covenant between God and the human ancestors. From then on, there began the betrayal and conflicts between God and human being. When God settled Adam in the Garden of Eden, he commanded the man, saying, "you may surely eat of every tree of the garden, but of the tree of the knowledge of good and evil you shall not eat, for in the day that you eat of it you shall surely die (Genesis 2:16-17)". However, even though the LORD God warned Adam and Eve by the punishment of death, they still betrayed God by eating the forbidden fruit after the seducing of the serpent "And the serpent said unto the woman, Ye shall not surely die: For God doth know that in the day ye eat thereof, then your eyes shall be opened, and ye shall be as gods, knowing good and evil (Genesis 3:4-5)." Eve believed the serpent because it said that "ye shall be as gods", this obviously shows Eve's betrayal of God, she wanted to be God, to have the equal status with God. As for Adam, if he absolutely obeyed God's will, he would not listen to Eve. Instead, he should criticize her for eating the forbidden fruit, and would not eat it himself. However, he ate it without even think of God's warning of death as if it did not exist. As written in the Bible "she took of the fruit thereof, and did eat, and gave also unto her husband with her; and he did eat (Genesis 3:6)."

\section{Mood Analysis of God-human Relationship}

Mood element has a clear defined semantic function: it carries the burden of the clause as an interactive event (Halliday, 2008: 120). In the following, three typical biblical stories are analyzed through the mood system of interpersonal meaning.

\subsection{The Tower of Babel \\ Imperative: power}

In the story The Tower of Babel, human gathered and said one to another "Go to, let us make brick, and burn them thoroughly and let us build us a city and a tower, whose top may reach unto heaven; and let us make us a name, lest we be scattered abroad upon the face of the whole earth (Genesis 11:3-4)". Human use the mood type of imperative in their communication, that is, the pattern of "let us", which highly imitates the words of God in creating human being themselves: "Let us make man in our image, after our likeness: and let them have dominion over the fish of the sea, and over the fowl of the air, and over the cattle, and over all the earth, and over every creeping thing that creeps on the earth (Genesis 1:26)." Such challenge against God is so obvious that God responded, "Go to, let us go down, and there confound their language, that they may not understand one another's speech (Genesis 11:7)", which resulted in human's scattering upon the face of all the earth, and the confounding of the language.

Here, the use of the imperative pattern of "let us" needs to be analyzed. The Hebrew word for "God" is "Elohim", which is a plural form. So "us" "our" in God's words for creating human being is for emphasis, and represents the greatness of God, which is called "the plural of majesty". Although the form is plural, the verb should still be single, which means that God is the only master of the universe (Liu, 2010). The distinction of let us and let's should also be clarified. The $u s$ in let's can include the addressee, but the $u s$ in let us excludes the addressee. Therefore, it is not difficult to understand why God use let us, for God is one and only one who masters the whole universe. But compare with words said by human in Genesis 11, they imitate the mood and sentence pattern of God, their use of "us" implies that human beings are united as one, which is so great that can contend with God. Thus, it is easy to see that human tried to take over the power of God, and tried to contend against God.

\subsection{Abraham Intercedes for Sodom \\ Interrogative: negotiation}

In the conversation between God and Abraham when he was interceding for Sodom, Abraham uses many interrogatives to question God, to consult with God, and to bargain with God step by step. "Will you indeed sweep away the righteous with the wicked? Suppose there are fifty righteous within the city. Will you then sweep away the place and not spare it for the fifty righteous who are in it? ... Shall not the Judge of all the earth do right?" When God answered, he required further "Behold, I have undertaken to speak to the Lord, I who am but dust and ashes. Suppose five of the fifty righteous are lacking. Will you destroy the whole city for the lack of five?" The Lord said "I will not destroy it if I find there forty-five there." Again he spoke and said, "Suppose forty are found there." And he said, "I will not do it for forty's sake." Then he said "Oh let not the LORD be angry, and I will speak. Suppose thirty are found there." And he said, "I will not do it, if I find thirty there." And he said, "Behold now, I have taken upon me to speak unto the LORD. Suppose there shall be twenty found there." And he said, I will not destroy it for twenty's sake." And he said, "Oh let not the LORD be angry, and I will speak yet but this once. Suppose ten shall be found there." And he said, "I will not destroy it for ten's sake." And the LORD went his way, as soon as he had left communing with Abraham, and Abraham returned unto his place.

In this conversation, Abraham tried to take advantage of God, and managed to bargain with him step by step by employing the yes/no interrogative of "will you/shall you". Therefore, Abraham dominated the conversation and induced God to accept his requirements.

\subsection{God Appeared to Moses}

\section{Vocatives: Initiating the dialogue}

When the angel of the LORD appeared unto Moses in a flame of fire out of the midst of a bush, God called unto him out of the midst of the bush, and said, "Moses, Moses!" And he said, "Here am I." (Exodus 3:4) It is God who initiates this conversation by calling out Moses' name. In using a Vocative the speaker (God) is enacting the participation of the 
addressee (Moses) or addressees in the exchange. This may serve to indentify the particular person (Moses) being addressed, or to call for that person's (Moses) attention. The Vocative is used by God to mark the interpersonal relationship, and thereby drew closer the relationship between God and Moses and also claimed superior status or power of God to Moses. However, Moses also employed Vocatives "Oh, my Lord (Exodus 4:10/13)" to complain and refuse God's demands as in "Oh, my Lord, I am not eloquent, either in the past or since you have spoken to your servant, but I am slow of speech and of tongue (Exodus 4:10)." And "Oh, my Lord, please send someone else (Exodus 4:13)." Vocatives are features of dialogue, especially casual conversation reinforcing the "you-and-me" dimension of the meaning.

\section{Imperatives: demanding}

God was constantly trying to establish a closer and harmonious interpersonal relationship between Moses and himself, trying to persuade him to be his representative to guide the Israel out of misery and groaning. But Moses was attempting to refuse God all the time, trying over and over again to break the interpersonal relationship. However, in their conversation, it is still God who dominates the whole situation. God kept using imperatives which represent "demanding" instead of "giving", for example, "Say this to the people of Israel (Exodus 3:15)" "Throw it on the ground (Exodus 4:3)." "Put out your hand and catch it by the tail (Exodus 4:4)." "Put your hand inside your cloak (Exodus 4:6)." And each time after God's demand, Moses did as what God said to him, showing that Moses was extremely passive over the whole conversation.

\section{Interrogative: anger}

Moses' constant refusing and excusing made God lose patient gradually, which is revealed through the change of mood types of God from indicatives to imperatives and then to interrogatives. God uses both WH-interrogatives/Yes-No interrogatives and rhetorical interrogatives to express his feelings and ideas. For example, "Who has made man's mouth? Who makes him mute, or deaf, or seeing, or blind? Is it not I, the LORD? (Exodus 4:11)" "Is there not Aaron, your brother, the Levite? (Exodus 4:14)" The interrogative mood of God indeed showed his anger towards Moses.

\section{Modality Analysis of God-human Relationship}

Modality in Hallidayan sense contains modalization and modulation. In the following, we carried out statistical analysis of modal verbs, modal adverbs and interpersonal metaphor so as to examine the god-human relationship in the Bible.

\subsection{Modalization and Modulation}

In a proposition, the meaning of the positive and negative pole is asserting and denying; positive 'it is so', negative 'it isn't so'. There are two kinds of intermediate possibilities: (i) degrees of probability: 'possibly/probably/certainly'; (ii) degrees of usuality: 'sometimes/usually/always'. The former are equivalent to 'either yes or no', that is, maybe yes, maybe no, with different degrees of likelihood attached. The latter are equivalent to 'both yes and no', that is, sometimes yes, sometimes no, with different degrees of oftenness attached. It is these scales of probability and usuality to which the term 'modality' strictly belongs. We shall refer to these, to keep them distinct, as modalization.

Both probability and usuality can be expressed in the same three ways: (a) by a finite modal operator in the verbal group (see Table 1, e.g. that will be John, he'll sit there all day; (b) by a modal Adjunct of (i) probability or (ii) usuality, e.g. that's probably John, he usually sits there all day; (c) by both together, e.g. that'll probably be John, he 'll usually sit there all day.

TABLE 1:

MODAL OPERATORS

\begin{tabular}{llll}
\hline & Low & Median & High \\
\hline $\begin{array}{l}\text { Positive } \\
\text { Negative }\end{array}$ & can, may, could, might, (dare) & will, would, should, is/ was to & must, ought to, need, has/ had to \\
& $\begin{array}{l}\text { needn't, dosen't/didn't + need } \\
\text { to, have to }\end{array}$ & $\begin{array}{l}\text { won't, wouldn't, shouldn't, (isn't/ } \\
\text { wasn't to) }\end{array}$ & $\begin{array}{l}\text { mustn't, oughtn't to, can't, couldn't, } \\
\text { (mayn't, mightn't, hasn't/ hadn't to) }\end{array}$ \\
\hline
\end{tabular}

In a proposal, the meaning of the positive and negative poles is prescribing and proscribing: positive 'do it', negative 'don't do it'. Here also there are two kinds of intermediate possibility, in this case depending on the speech function, whether command or offer. (i) In a command, the intermediate points represent degrees of obligation: 'allowed to/supposed to/required to'; (ii) in an offer, they represent degrees of inclination: 'willing to/anxious to/determined to'. We shall refer to the scales of obligation and inclination as modulation, to distinguish them from modality in the other sense, that which we are calling modalization.

Again, both obligation and inclination can be expressed in either of two ways, though not, in this case, by both together: (a) by a finite modal operator, e.g. you should know that, I'll help them; (b) by an expansion of the Predicator, (i) typically by a passive verb, e.g. you're supposed to know that, (ii) typically by an adjective, e.g. I'm anxious to help them. Modality has three values, namely high, median and low. Please see Table 2 for specification.

TABLE 2:

THREE "VALUES" OF MODALITY

\begin{tabular}{lllll}
\hline & Probability & Usuality & Obligation & Inclination \\
\hline High & certain & always & required & determined \\
Median & probable & usually & supposed & keen \\
Low & possible & sometime & allowed & willing \\
\hline
\end{tabular}




\subsection{Statistics and Analysis}

\subsubsection{Modal Verbs}

According to statistics, the numbers of each type of modal operators and adverbs serving as mood adjuncts of modality, including low, median and high, are counted (see Table 3).

TABLE 3:

STATISTICS OF MODAL OPERATORS IN THE WHOLE OT

\begin{tabular}{|c|c|c|c|c|}
\hline Value & $\begin{array}{l}\text { Modal } \\
\text { Adverbs }\end{array}$ & Number & $\begin{array}{l}\text { Total } \\
\text { number }\end{array}$ & Percentage \\
\hline \multirow[t]{2}{*}{ High } & Must & 49 & \multirow[t]{2}{*}{53} & \multirow[t]{2}{*}{$0.344 \%$} \\
\hline & Ought to & 4 & & \\
\hline \multirow[t]{4}{*}{ Median } & Shall & 9961 & \multirow[t]{4}{*}{14108} & \multirow[t]{4}{*}{$91.581 \%$} \\
\hline & Should & 536 & & \\
\hline & Will & 3513 & & \\
\hline & Would & 298 & & \\
\hline \multirow[t]{2}{*}{ Low } & May & 977 & \multirow[t]{2}{*}{1244} & \multirow[t]{2}{*}{$8.075 \%$} \\
\hline & Might & 267 & & \\
\hline
\end{tabular}

From the statistics, it is found that modal operators at median value are used most frequently, while modal auxiliaries at outer value are obviously negligible compared with median value. The dominantly less use of high value modal verbs like must and ought to is not for the purpose of degenerating the status and power of the speaker (God, the leader etc.), expressing hesitation or uncertainty, but instead, to declare, to demand and to take responsibilities. In fact, it is a revealing of the speakers' overwhelming ideology (Ji, 2011).

"Shall" is used to express the obligation or duty of the speaker. "Will" reveals the willingness of the speaker. They are both subjective and implicit, representing the feelings and ideas of the implied speaker. According to another statistic of the percentage of modal auxiliaries used by God and his people (see Table 4), we can find that modal auxiliaries are mostly used by God, while others are negligible. It is not hard to interpret this phenomenon, the reason is that God is the master of the whole universe, and he has his own freewill (subjective, implied by modal auxiliaries) dominated over all the other creatures, while human's will are subjective to God, they cannot freely express their own ideas and feelings, instead, what they can do is just reporting or imitating the ideas or information received from God (objective, implied by modal adverbs, see Table 5). This part will be analyzed in the following.

Followings are some examples for analysis:

(1) I will watch over it and protect it for all time. (2 Chronicles 7:16)

(2) But I will bless the person who puts his trust in me. (Jeremiah 17:7)

(3) But of the tree of the knowledge of good and evil you shall not eat, for in the day that you eat of it you shall surely die. (Genesis 3:17)

(4) If it gores a man's son or daughter, he shall be dealt with according to this same rule. (Exodus 22:31)

We can see form the above examples that verbs after modal auxiliary will are watch, protect and bless. Therefore, what will express is the commitment and responsibility towards his people. When God use will, he also plus the subject $I$ for emphasis, revealing clearly that it is God's own freewill to protect and bless his chosen people, not under the pressure of external factors. Through the use of will, God shows his power and responsibility to his chosen people, and also shows his own nature. Meanwhile, God win more support from his people. Will acts as a close tie between Cod and his people, bridging the gap between them. This surely helps to build a closer God-human interpersonal relationship (Ji, 2011). On the other hand, verbs come after shall or shall not are eat, die and be dealt with. Shall or shall not is a sign showing God's authority and supremacy, but God does not chose must or must not that of high value to forbid doing something, instead, he uses the median one. The purpose is to offer more choices and freedom to his people. What the God provides is only a rule, a criteria, but whether human will obey or violate it is surely depend on people themselves. Thus, we can find that God is indeed trying to respect man, to offer choices for them to either go to heaven or hell.

TABLE 4:

MODAL AUXILIARIES USED BY GOD AND HIS PEOPLE (JI, 2011)

\begin{tabular}{lllll}
\hline Modal auxiliaries & God & & Moses & \\
& Total number & Percentage & Total number & Percentage \\
\hline will & 62 & $54.87 \%$ & 4 & $36.36 \%$ \\
must & 22 & $19.47 \%$ & 0 & $0 \%$ \\
mustn't & 5 & $4.42 \%$ & 1 & $9.09 \%$ \\
can & 9 & $7.96 \%$ & 2 & $18.18 \%$ \\
can't & 0 & $0 \%$ & 1 & $9.09 \%$ \\
might & 1 & $0.88 \%$ & 0 & $0 \%$ \\
may & 6 & $5.31 \%$ & 0 & $0 \%$ \\
shall & 7 & $6.19 \%$ & 1 & $9.09 \%$ \\
should & 0 & $0 \%$ & 2 & $18.18 \%$ \\
needn't & 1 & $0.88 \%$ & 0 & $0 \%$ \\
total & 113 & & 11 & \\
\hline
\end{tabular}




\begin{tabular}{lllll}
\hline Modal auxiliaries & $\begin{array}{l}\text { God } \\
\text { Total number }\end{array}$ & Percentage & $\begin{array}{l}\text { Solomon } \\
\text { Total number }\end{array}$ & Percentage \\
\hline will & 11 & $91.67 \%$ & 0 & $0 \%$ \\
shall & 1 & $8.32 \%$ & 0 & $0 \%$ \\
total & 12 & & 0 & \\
\hline & & & & \\
\hline Modal auxiliaries & God & Percentage & Total number & Percentage \\
& Total number & $64.9 \%$ & 2 & $15.4 \%$ \\
\hline will & 61 & $8.51 \%$ & 1 & $7.69 \%$ \\
must & 8 & $6.38 \%$ & 0 & $0 \%$ \\
mustn't & 6 & $8.51 \%$ & 3 & $23.08 \%$ \\
would & 8 & $1.06 \% \%$ & 1 & $2.69 \%$ \\
wouldn't & 1 & $3.19 \%$ & 3 & $23.08 \%$ \\
can't & 3 & $4.26 \%$ & 3 & $0 \%$ \\
can & 4 & $1.06 \%$ & 0 & $0 \%$ \\
have to & 1 & $1.06 \%$ & 0 & $0 \%$ \\
should & 1 & $1.06 \%$ & 0 & \\
shouldn't & 1 & & 13 & \\
total & 94 & & & \\
\hline
\end{tabular}

\subsubsection{Modal Adverbs}

\section{Probability}

TABLE 5:

PROBABILITY

\begin{tabular}{|c|c|c|c|c|}
\hline Value & $\begin{array}{l}\text { Modal } \\
\text { Adverbs }\end{array}$ & Number & $\begin{array}{l}\text { Total } \\
\text { number }\end{array}$ & Percentage \\
\hline \multirow[t]{4}{*}{ High } & Certain & 64 & \multirow{4}{*}{402} & \multirow{4}{*}{$99.259 \%$} \\
\hline & Certainly & 30 & & \\
\hline & Surely & 277 & & \\
\hline & Indeed & 31 & & \\
\hline \multirow[t]{2}{*}{ Median } & Probable & 0 & \multirow[t]{2}{*}{0} & \multirow[t]{2}{*}{0} \\
\hline & Probably & 0 & & \\
\hline \multirow[t]{3}{*}{ Low } & Possible & 0 & \multirow{3}{*}{3} & \multirow{3}{*}{$0.0741 \%$} \\
\hline & Possibly & 0 & & \\
\hline & Hardly & 3 & & \\
\hline
\end{tabular}

According to statistics, high degree of probability are used almost by human, that is because modal adverbs are objective and implicit, human only reports God's will, not their own will. As God is the master of the whole universe, he rarely uses modal adverbs, what he uses is modal verbs which implies his subjectivity and his own freewill.

Even a high value modal ('certainly', 'always') is less determinate than a polar form: that's certainly John is less certain than that's John; it always rains in summer is less invariable than it rains in summer. In other words, you only say you are certain when you are not (Halliday, 2008:147). This is why God seldom uses modal adverbs.

\section{Usuality}

\begin{tabular}{|c|c|c|c|c|}
\hline \multicolumn{5}{|c|}{$\begin{array}{l}\text { TABLE 6: } \\
\text { USUALITY }\end{array}$} \\
\hline Value & Modal Adverbs & Number & $\begin{array}{l}\text { Total } \\
\text { number }\end{array}$ & Percentage \\
\hline \multirow[t]{2}{*}{ High } & Always & 42 & \multirow[t]{2}{*}{90} & \multirow[t]{2}{*}{$100 \%$} \\
\hline & Never & 48 & & \\
\hline Median & Usually & 0 & & 0 \\
\hline Low & Sometimes & 0 & & 0 \\
\hline
\end{tabular}

It is shown in Table 6 that what exists in the Bible is all usuality of high value, that is, adverbs like always and never. The result implies that regulations must be observed, because rules are created by God, they are either black or white, either right or wrong, and there are no conditions in between. Obedience will definitely win blessings from God, while rebellion will surely get punished.

Obligation

TABLE 7:

OBLIGATION

\begin{tabular}{llll}
\multicolumn{3}{c}{ OBLIGATION } \\
\hline Value & $\begin{array}{l}\text { Modal } \\
\text { Adverbs }\end{array}$ & Number & Percentage \\
& Required & 15 & $100 \%$ \\
High & Supposed & 0 & 0 \\
Low & Allowed & 0 & 0 \\
\hline
\end{tabular}

The existence of only high value reveals the objectivity of obligation in Bible. The word "required" are used all by God's people, thus proves that human are required to obey the God. 


\section{Inclination}

\begin{tabular}{lllll}
\multicolumn{5}{c}{$\begin{array}{c}\text { TABLE 8: } \\
\text { INCLINATION }\end{array}$} \\
\hline Value & Modal Adverbs & Number & $\begin{array}{l}\text { Total } \\
\text { number }\end{array}$ & Percentage \\
\hline High & Determined & 16 & 16 & $33.3 \%$ \\
Median & Keen & 0 & 0 & 0 \\
Low & Willing & 13 & 32 & $66.7 \%$ \\
\cline { 2 - 3 } & Willingly & 19 & & \\
\hline
\end{tabular}

Apart from the low inclination represented by "willing/willingly", which has already been analyzed in the above section (modal auxiliary "will"), all the values appear in Bible of inclination is of high value. This phenomenon indicates that decisions are made by Lord the God, while people who use the word have no subjectivity. The ending is destined by God.

The word "determined" are almost all used to make absolute assertions by human. For example, David said to Jonathan, "but if he be very wroth, then be sure that evil is determined by him (1 Samuel 20:7)."

\subsubsection{Interpersonal metaphors}

TABLE 9:

\begin{tabular}{ll}
\multicolumn{2}{c}{ INTERPERSONAL METAPHORS } \\
\hline I am sure + clause & 1 \\
I know + clause & 37 \\
\hline
\end{tabular}

There are also interpersonal metaphors in the Bible, for example, God said to Moses, "And I am sure that the king of Egypt will not let you go, no, not by a mighty hand (Exodus 3:19)." "I am sure that" is followed by a clause, and this is where the grammatical metaphor takes place. These metaphors are subjective and explicit. Why it is subjective is that it begins with the subject "I", and why it is explicit is that the subject "I" exists in the proposition instead of hidden by using modal verbs.

Examples of "I know + clause":

(5) When Abram was about to enter Egypt, he said to Sarai his wife, "I know that you are a woman beautiful in appearance ..." (Genesis 12:11)

(6) God said to Abimelech in the dream, "yes, I know that you have done this in the integrity of your heart..." (Genesis 20:6)

(7) The angel of the Lord said to Abraham, "Do not lay your hand on the boy or do anything to him, for now I know that you fear God..." (Genesis 22:12)

Form the above examples we can find that the circumstances where the speaker uses "I know + clause", there are hierarchical relations between the two speakers, and the one who use the clause is the one who possesses higher positions. In (5), Abram has higher position than Sarai his wife; in (6), God has higher position than Abimelech; in (7), God's angel has higher position than Abraham.

"I know + clause" is subjective and explicit, as projecting mental clause + idea clause. In the Bible, there exists obvious and highly intensified hierarchy, thus, only the one who has higher status can express their ideas or feelings subjectively to the lower ones.

\section{CONCLUSION}

Systemic functional grammar represented by Halliday identifies three metafunctions of language, i.e. ideational, interpersonal and textual. Among them, interpersonal function is explained as closely related to the human activity of communication, but it has been studied less systematically than the other two because it is more complex and less systematic.

In the study of the interpersonal meaning of biblical language, the author makes the research both from micro and macro levels, from mood to modality to interpersonal metaphor, so as to reach the conclusion that interpersonal meaning in biblical language has directly or indirectly helped to make closer relationship between God and his people. Mood and modality in the Bible helps construct positive interpersonal relationships.

The context of this study mainly concerns the Bible itself, but further researches could also extends to all of human society both in and outside the Bible. So the participants in our interaction have a very large scope. Besides God, there are also people both inside and outside the Bible ( $\mathrm{Ji}, 2007)$. The interaction between different people in this research is relatively complex, which includes not only that between God and his people, that among his people themselves, but also that between the writer and readers.

\section{REFERENCES}

[1] The Holy Bible, King James Version. (1999). New York: American Bible Society. www.bartleby.com/108/.

[2] Halliday, M.A.K. (2008). An introduction to functional grammar (3rd ed). London: Edward Arnold Ltd. 
[3] Ji, H.Q. (2007). The interpersonal metafunction of mood in biblical language. Journal of Xiangtan University (Philosophy and Social Sciences), 5, 148-150.

[4] Ji, H.Q. (2011). The interpersonal meaning of modality in biblical language. Language Teaching and Research, 2, $230-238$.

[5] Liu, Y.Q. (2010). Course book of literary explanation of the Bible. Beijing: Peking University Press.

Xi Wang was born in Kaifeng, China in 1988. She is currently a Ph.D. student in College of International Studies, Southwest University. Her research interests are systemic functional grammar, language complexity and translation theory. 